\title{
Determination of Pre-service Classroom Teachers' Technological Pedagogical Content Knowledge ${ }^{1}$
}

\author{
Şendil Can ${ }^{1}$, Serpil Doğru ${ }^{1}$, Gülsu Bayir ${ }^{1}$ \\ ${ }^{1}$ Mugla Sitk1 Kocman University, Turkey \\ Correspondence: Şendil Can, Mugla Sıtkı Kocman University, Turkey.
}

Received: December 16, 2016

Accepted: January 7, 2017

Online Published: January 12, 2017

doi:10.11114/jets.v5i2.2083

URL: http://dx.doi.org/10.11114/jets.v5i2.2083

\begin{abstract}
It seems to be a must for teachers and pre-service teachers to have information and skills necessary for the use of technology in education. This requires effective planning of how technology should be integrated into the teacher training curriculums of education faculties and continuous revision of this plan. In this regard, the purpose of the current study is to investigate the pre-service classroom teachers' technological pedagogical content knowledge in relation to grade level and gender variables. The current study employing the survey model was conducted on 136 first and third year students from the Classroom Teacher Education Department of the Education Faculty at Mugla Sitki Kocman University in the fall term of 2015-2016 academic year. As a data collection tool, a 47-item, 7-factor and five-point Likert type Technological Pedagogical Content Knowledge Scale was used. The collected data were analyzed with independent samples t-test. The findings of the test revealed that the pre-service classroom teachers' technological pedagogical content knowledge and opinions about the sub-factors do not vary significantly depending on gender and grade level; however, their opinions about the sub-factor of technological knowledge vary significantly depending on grade level.
\end{abstract}

Keywords: technology, content knowledge, pedagogy, pre-service classroom teacher, TPCK

\section{Introduction}

The most basic building block of the construction of the 21st century technology age is technology. Technology is not a privilege any longer in that its use has become a necessity in every part of life. Thus, it has become inevitable to integrate technology into education. Education and use of technology in education have become two concepts indispensable from each other (Komis, Ergazakia and Zogzaa, 2007; McCannon \& Crews, 2000). Life-long learning can be realized by means of technology (Öztürk and Horzum, 2011).

The most important educational organizations that should follow scientific and technological developments are schools. Accordingly, it seems to be necessary to bring information and communication technologies into school environments, to use them effectively and make them widespread in these environments. In this regard, the responsibility to be undertaken by teachers is great. Teachers and pre-service teachers are the main determiners of the extent to which technology will be adopted in educational environments (Heinich, Molenda, Russell and Smaldino, 2002). Therefore, teachers and pre-service teachers should be equipped with information and skills necessary to use technology in educational environments (Öztürk and Horzum, 2011). For teachers to be able to integrate technology into their classes, they need to be technology-competent professionals. For the integration of technology with teaching process, in addition to profound technological knowledge, information about which technology is used where, how and why should be possessed by teachers (Kuşkaya Mumcu, Haşlaman and Usluel, 2008).

When information and skill-based training given to teachers is examined, it is seen that it is primarily content-focused (Shulman, 1986). For classes to be efficient, teachers, besides content knowledge, should have some other competencies. A great deal of international research has focused on elicitation of what should be known by teachers and what they should be able to do and the competencies to be possessed by teachers are discussed under the heading of Pedagogical

\footnotetext{
${ }^{1}$ This study was presented at 15th International Primary Teacher Education Symposium on May 11-14, 2016, Muğla Sttkı Koçman University, Muğla, TURKEY.
} 
Content Knowledge (PCK) (Timur and Taşar, 2011). Introduced by Shulman (1986), the concept of Pedagogical Content Knowledge (PCK) directed educators' attention to content education. Seriously studied and modeled in science education, PCK is the knowledge of how to convert a known concept or heading into a meaningful learning rather than the general pedagogical knowledge of how something can be taught (Magnusson, Krajcik and Borko, 1999). According to Shulman (1986), PCK goes beyond the subject in education in order to understand the dimension of the subject and PCK establishes the link between pedagogy and content knowledge. As such, in the literature it emphasized that pedagogical content knowledge is as important as content knowledge and professional knowledge (Mandacı Şahin, Yenmez, Özpınar and Köğce, 2013).

With the acceleration of the integration of technology into education, the technology dimension was added by Msihra and Koehler to the concept of pedagogical content knowledge and thus the concept of Technological Pedagogical Content Knowledge (TPCK) was constructed (Koehler and Mishra, 2005a, 2005b). Koehler and Mishra (2009) defines TPCK as a whole constructing the basis of education through technology, involving the presentation of concepts by using technology and the development of constructivist methods by means of pedagogical techniques. Niess (2005) defines technological pedagogical content knowledge as the integration of learning, teaching and technological development and content knowledge. TPCK addresses three basic dimensions which are pedagogic, technological and content knowledge necessary for teaching competency and the relationship of each dimension with the other Çuhadar, Bülbül and Ilgaz, 2013).

In TPCK, there are seven domains of knowledge created by the combination of technological, pedagogical and content knowledge. These are; Technology Knowledge, Content Knowledge, Pedagogical Knowledge, Pedagogical Content Knowledge, Technological Content Knowledge, Technological Pedagogical Knowledge and Technological Pedagogical Content Knowledge. This structure is presented in figure 1 (Harris, Mishra and Koehler, 2007; Mishra and Koehler, 2006).

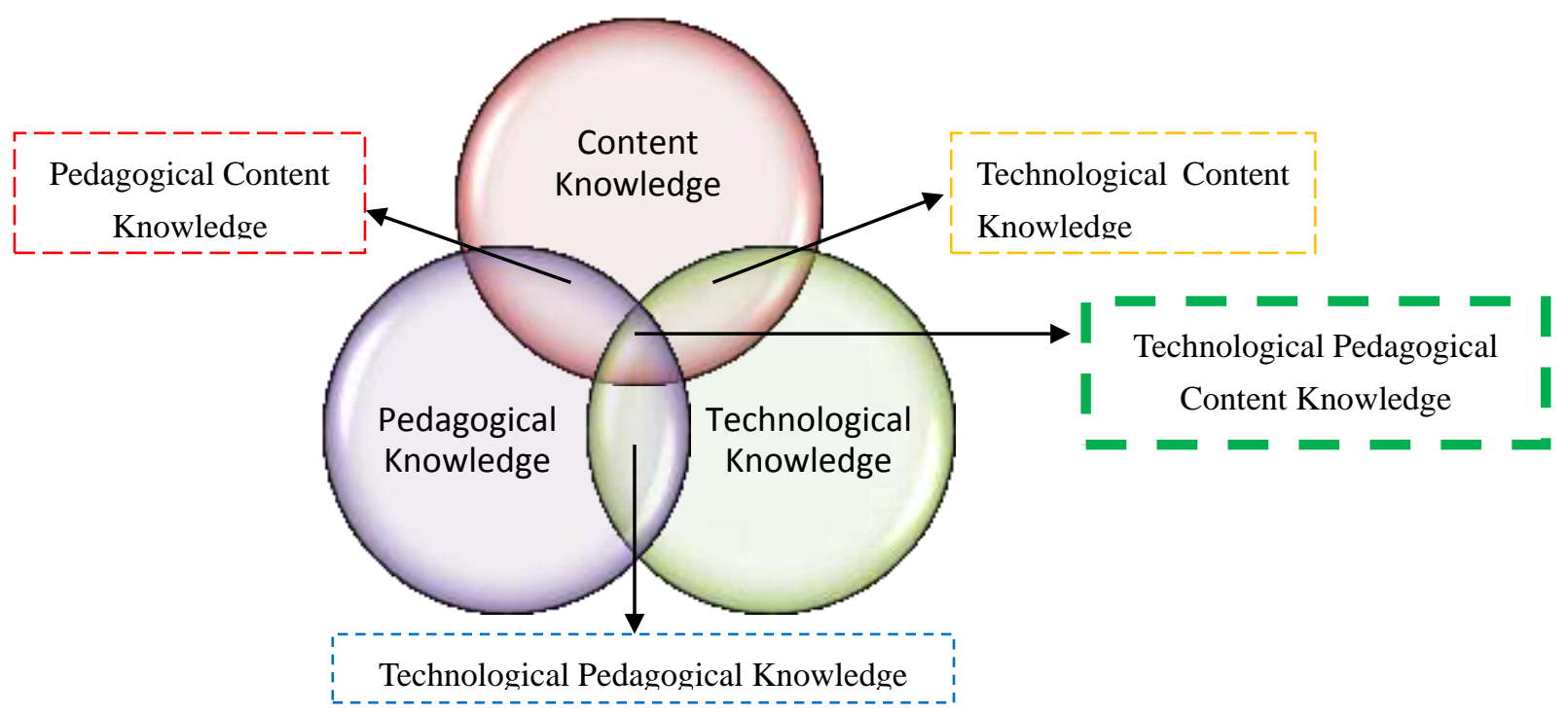

Figure 1. Technological pedagogical content knowledge framework and knowledge components

The meanings of the seven components in the TPCK framework are explained by Mishra

Mishra and Koehler (2006) as follows:

- Content Knowledge $(C K)$ : It is the knowledge that needs to be learned by or taught to teachers or pre-service teachers.

- Pedagogical Knowledge (PK): It is the knowledge about which approaches should be adopted to teach the target topic of instruction best by teachers and pre-service teachers.

- Technological Knowledge (TB): This is the knowledge possessed by teachers or pre-service teachers about standard (black board, book etc.) and digital technologies (video, narration, smart board, educational software etc.)

- Pedagogical Content Knowledge (PCK): It is the knowledge about the instructional approaches to be used to teach a content. 
- Technological Pedagogical Knowledge (TPK): It is the teacher or pre-service teacher's knowledge about capacities of technologies and how these capacities will change education.

- Technological Content Knowledge (TCK): It is the teacher or pre-service teacher's knowledge about the fact that technological and content knowledge is related to each other.

- Technological Pedagogical Content Knowledge (TPCK): It is the teacher or pre-service teacher's knowledge constituted by the combination of technological, pedagogical and content knowledge about the technologies and instructional approaches that can be used to teach a specific topic related to content. Niess (2005) argued that emergence of TPCK model is not coincidental and identified the variables involved in this process as follows:

$\checkmark$ Profound understanding of what instruction in which technology is integrated with learning process means,

$\checkmark$ Determination of instructional strategies and techniques directed towards teaching of a subject with the help of technology,

$\checkmark$ Having knowledge about the learning status of students to learn in relation to technology-enhanced teaching of a specific subject,

$\checkmark$ Having knowledge about technologies and materials to be used for the integration of technology with learning process.

In literature there are some studies focusing on this issue. Some of them are discussed here. Sancar Tokmak, Yavuz Konokman and Yanpar Yelken, (2013) used the Technological Pedagogical Content Knowledge Self-efficacy Scale to investigate whether the pre-service pre-school teachers' self-efficacy perceptions of TPCK vary significantly depending on grade level and gender variables. They found that the pre-service pre-school teachers' self-efficacy perceptions of TPCK are high. Moreover, it was determined that the pre-school pre-service teachers' self-efficacy perceptions of TPCK did not vary significantly depending on grade level and gender variables. Gömleksiz and Fidan (2011); in their study aiming to determine the pre-service classroom teachers' self-efficacy perceptions of technological pedagogical content knowledge, used the Technological Pedagogical Content Knowledge Scale developed by Schmidt et. al. (2009) and adapted to Turkish by Öztürk and Horzum (2011). They concluded that the pre-service classroom teachers' self-efficacy perceptions of technological pedagogical content knowledge did not vary significantly depending on gender variable but significantly varied depending on university variable. Kaya et al. (2011) attempted to determine the pre-service technology teachers' self-efficacy perceptions of technological pedagogical content knowledge and found that many of the pre-service teachers have high level self-efficacy perceptions of technological pedagogical content knowledge. No gender-based significant difference among the pre-service teachers' self-efficacy perceptions was found. The results also revealed that there are significant differences among the pre-service teachers' self-efficacy perceptions of the sub-dimensions of technological knowledge, content knowledge, technological content knowledge, technological pedagogical knowledge and technological pedagogical content knowledge depending on faculty type variable.

It is clear that the education given to pre-service teachers has an important influence on teachers' use of information and communication technologies in their classes. Pre-service teachers' knowledge about communication technologies is of great importance for meaningful, effective and proper use of these technologies in their classroom applications. There is a great deal of research indicating that integration of technological skills with pedagogical and content knowledge enhances pre-service teachers' self-efficacy and self-confidence. Teachers with high levels of self-efficacy and self-confidence can teach their classes more effectively and efficiently. Moreover, TPCK should be possessed by teachers that can work at every level of schooling ranging from elementary education to higher education. The teachers and pre-service teachers teaching at elementary and secondary levels are particularly expected to have high levels of TPCK. Therefore, it was decided to conduct the current study on pre-service classroom teachers. In this regard, the purpose of the current study is to determine the effect of gender and grade level variables on pre-service classroom teachers' Technological Pedagogical Content Knowledge and its sub-dimensions. To this end, answers to the following sub-problems were sought.

1. Does the pre-service classroom teachers' TPCK vary significantly depending on gender and grade level variables?

2. Do the pre-service classroom teachers' scores for the sub-dimensions of TPCK scale (Technological Knowledge, Content Knowledge, Pedagogical Knowledge, Pedagogical Content Knowledge, Technological Content Knowledge, Technological Pedagogical Knowledge, Technological Pedagogical Content Knowledge) vary significantly depending on gender and grade level variables?

\section{Methodology}


The study employed the survey model. The survey model is a research method aiming to describe a past or present situation as it was or is. The subject of the research is described as it is in its natural conditions (Karasar, 2012).

\subsection{Sampling}

The randomly selected sampling of the study consists of a total of 136 students (69 are first-year students and 67 are third year students) attending the Classroom Teacher Education Department of the Education Faculty of Mugla Sitki Kocman University in the fall term of 2015-2016 academic year.

\subsection{Data Collection Tools}

The data of the study were collected by using the 47-item, 7-factor, 5-point Likert type Technological Pedagogical Content Knowledge Scale developed by Schmidt et. al. (2009) and adapted to Turkish by Öztürk and Horzum (2011). As all the items in the scale are positive, the pre-service teachers' responses to them are evaluated on the basis of the following coding "Strongly Disagree (1), "Disagree (2)", "Undecided (3)", "Agree (4)", "Strongly Agree (5)". For the Turkish version of the scale, Cronbach Alpha internal consistency coefficient was found to be 0.96 . For the factors of the scale, the reliability coefficients are; Technology Knowledge 0.82, Content Knowledge 0.75, Pedagogical Knowledge 0.84, Pedagogical Content Knowledge 0.85, Technological Content Knowledge 0.80, Technological Content Knowledge 0.86 and Technological Pedagogical Content Knowledge 0.92. The Cronbach Alpha reliability coefficient calculated over the data of the current study was found to be 0.94 and for its sub-dimensions, the coefficients are as follows: Technological Knowledge 0.87, Content Knowledge 0.82, Pedagogical Knowledge 0.82, Pedagogical Content Knowledge 0.72, Technological Content Knowledge 0.73, Technological Pedagogical Knowledge 0.77 and Technological Pedagogical Content Knowledge 0.81.

The first factor of the scale is "Technological Knowledge" including seven items related to knowledge about the use of technology. The second factor is "Content Knowledge" including twelve items related to knowledge about mathematics, social studies, science and literacy. The third factor including seven items related to knowledge about classroom management, evaluation, plan development, teaching process and methods is "Pedagogical Knowledge". The fourth factor is "Pedagogical Content Knowledge" including four items related to content knowledge used to manage the teaching process. The fifth factor is "Technological Content Knowledge" including four items related to how technology should be used in understanding and using of the concepts in the content areas by students. The sixth factor is "Technological Pedagogical Knowledge" including five items related to which technology should be used with which instructional methods and how. The seventh factor is "Technological Pedagogical Content Knowledge" including eight items related to integration of instructional technologies by teachers.

\subsection{Data Analysis}

Whether the pre-service classroom teachers' knowledge about technological pedagogical content and its sub-dimensions varies significantly depending on gender and grade level variables was tested with independent samples t-test.

\section{Findings}

In this section, the analyses conducted in line with the sub-problems are presented in tables and interpreted. The first sub-problem is "Does the pre-service classroom teachers' TPCK vary significantly depending on gender and grade level variables? The results of independent samples t-test related to this question are given in Tables 1 and 2.

Table 1. T-test results related to the distribution of TPCK scale scores across genders

\begin{tabular}{lllllll}
\hline Gender & $\mathrm{N}$ & $\bar{X}$ & $\mathrm{~S}$ & $\mathrm{sd}$ & $\mathrm{t}$ & $\mathrm{p}$ \\
\hline Female & 97 & 169.69 & 20.00 & 133 & -.58 & .56 \\
Male & 39 & 171.97 & 22.60 & & & \\
\hline
\end{tabular}

When Table 1 is examined, it is seen that the pre-service teachers' TPCK scores do not vary significantly depending on gender $\left[\mathrm{t}_{(133)}=-0.58, \mathrm{p}>.05\right]$. The difference found between the female students' TPCK scores and the male students' score is not statistically significant.

The results of the t-test conducted to determine whether the pre-service teachers' TPCK scores vary significantly depending on grade level are given in Table 2.

Table 2. T-test results related to distribution of TPCK scale scores across grade levels

\begin{tabular}{lllllll}
\hline Grade Level & $\mathrm{N}$ & $\bar{X}$ & $\mathrm{~S}$ & $\mathrm{sd}$ & $\mathrm{t}$ & $\mathrm{p}$ \\
\hline $1^{\text {st }}$ year & 69 & 167.25 & 19.5 & 133 & -1.79 & .07 \\
$3^{\text {rd }}$ year & 67 & 173.59 & 21.6 & & &
\end{tabular}

When Table 2 is examined, it is seen that the pre-service teachers' TPCK scores do not vary significantly depending on grade level $\left[\mathrm{t}_{(133)}=-1,79, \mathrm{p}>.05\right]$. It is seen that the difference between the first year students' TPCK scores and the third year students' TPCK scores is not statistically significant. 
The results of the independent samples t-test conducted to analyze whether the pre-service teachers' scores taken for the sub-dimensions of TPCK scale vary significantly depending on gender and grade level variables are presented in Table 3 and Table 4.

Table 3. T-test results related to the distribution of the scores for the sub-dimensions of TPCK scale across genders

\begin{tabular}{llllllll}
\hline Factors & Gender & $\mathrm{N}$ & $\bar{X}$ & $\mathrm{~S}$ & $\mathrm{sd}$ & $\mathrm{t}$ & $\mathrm{p}$ \\
\hline Technology Knowledge & Female & 97 & 24.16 & 4.49 & 134 & -1.52 & .13 \\
& Male & 39 & 25.56 & 5.62 & & & \\
Content Knowledge & Female & 97 & 40.57 & 5.94 & 134 & -1.48 & .14 \\
& Male & 39 & 42.38 & 7.65 & & & \\
Pedagogical Knowledge & Female & 97 & 27.12 & 3.53 & 134 & -.19 & .85 \\
& Male & 39 & 27.25 & 3.86 & & & \\
Pedagogical Knowledge & Female & 97 & 14.53 & 2.34 & 134 & .43 & .66 \\
& Male & 39 & 14.33 & 2.72 & & & \\
Technological Content Knowledge & Female & 97 & 13.88 & 2.59 & 134 & -.17 & .87 \\
& Male & 39 & 13.97 & 3.06 & & & \\
Technological Pedagogical Knowledge & Female & 97 & 19.26 & 2.78 & 134 & 1.14 & .26 \\
& Male & 39 & 18.64 & 3.16 & & & \\
\hline Technological Pedagogical Content Knowledge & Female & 97 & 30.37 & 4.09 & 134 & .67 & .50 \\
& Male & 39 & 29.82 & 4.78 & & & \\
\hline
\end{tabular}

When Table 3 is examined, it is seen that the pre-service teachers' scores taken from the sub-factors (Technology Knowledge, Content Knowledge, Pedagogical Knowledge, Pedagogical Content Knowledge, Technological Content Knowledge, Technological Pedagogical Knowledge and Technological Pedagogical Content Knowledge) do not vary significantly depending on gender.

Table 4. T-test results related to the distribution of the scores for the sub-dimensions of TPCK scale across grade levels

\begin{tabular}{|c|c|c|c|c|c|c|c|}
\hline Factors & Grade Level & $\mathrm{N}$ & $X$ & $S$ & $\mathrm{Sd}$ & $\mathrm{t}$ & $\mathrm{p}$ \\
\hline Technological & $1^{\text {st }}$ grade & 69 & 23.69 & 5.22 & 134 & -2.15 & .03 \\
\hline Knowledge & $3^{\text {rd }}$ grade & 67 & 25.46 & 4.32 & & & \\
\hline \multirow[t]{2}{*}{ Content Knowledge } & $1^{\text {st }}$ grade & 69 & 40.05 & 6.18 & 134 & -1.91 & .06 \\
\hline & $3^{\text {rd }}$ grade & 67 & 42.18 & 6.71 & & & \\
\hline Pedagogical & $1^{\text {st }}$ grade & 69 & 27.15 & 3.49 & 134 & -.01 & .99 \\
\hline Knowledge & $3^{\text {rd }}$ grade & 67 & 27.16 & 3.76 & & & \\
\hline Pedagogical Content & $1^{\text {st }}$ grade & 69 & 14.10 & 2.41 & 134 & -1.83 & .07 \\
\hline Knowledge & $3^{\text {rd }}$ grade & 67 & 14.86 & 2.44 & & & \\
\hline Technological & $1^{\text {st }}$ grade & 69 & 13.62 & 2.53 & 134 & -1.25 & .21 \\
\hline Content Knowledge & $3^{\text {rd }}$ grade & 67 & 14.21 & 2.90 & & & \\
\hline Technological & $1^{\text {st }}$ grade & 69 & 18.66 & 2.93 & 134 & -1.73 & .08 \\
\hline $\begin{array}{l}\text { Pedagogical } \\
\text { Knowledge }\end{array}$ & $3^{\text {rd }}$ grade & 67 & 19.52 & 2.81 & & & \\
\hline Technological & $1^{\text {st }}$ grade & 69 & 29.94 & 4.07 & 134 & -.75 & .46 \\
\hline $\begin{array}{l}\text { Pedagogical Content } \\
\text { Knowledge }\end{array}$ & $3^{\text {rd }}$ grade & 67 & 30.49 & 4.52 & & & \\
\hline
\end{tabular}

As can be seen in Table 4, the scores taken by the pre-service teachers from the sub-dimension of Technological Knowledge vary significantly depending on grade level $\left[\mathrm{t}_{(134)}=-2.15, \mathrm{p}<.05\right]$. The third year students' Technological Knowledge mean score ( $X=25.46$ ) is more positive than the first year students' Technological Knowledge mean score ( $\bar{X}=23.69)$. Thus, it can be argued that there is a significant correlation between Technological Knowledge and grade level. The other sub-factors; Content Knowledge, Pedagogical Knowledge, Pedagogical Content Knowledge, Technological Content Knowledge, Technological Pedagogical Knowledge and Technological Pedagogical Content Knowledge do not vary significantly depending on grade level.

\section{Discussion}

In the current study, it was investigated whether the pre-service classroom teachers' Technological Pedagogical Content Knowledge and knowledge about its sub-factors vary significantly depending on their gender and grade level. It was found that the pre-service teachers' Technological Pedagogical Content Knowledge did not vary significantly depending on gender and grade level. Thus, it can be argued that the pre-service teachers' gender and grade level do not affect their Technological Pedagogical Content Knowledge. Similarly, Sancar Tokmak et al. (2013), Gömleksiz and Fidan (2011) and Kaya et al. (2011) reported that Technological Pedagogical Content Knowledge did not vary significantly depending on gender in their studies. This finding concurs with the finding of the current study. It was also found that the gender does not have a significant influence on the pre-service teachers' Technological Knowledge, Content Knowledge, Pedagogical Knowledge, Pedagogical Content Knowledge, Technological Content Knowledge, Technological Pedagogical Knowledge and Technological Pedagogical Knowledge and Technological Pedagogical 
Content Knowledge. Öztürk (2013) also reported that the pre-service classroom teachers' technological knowledge, content knowledge, pedagogical content knowledge, technological content knowledge, technological pedagogical knowledge and technological pedagogical content knowledge are not affected from gender. While this finding supports the finding of the current study, Öztürk also found that Pedagogical Knowledge sub-factor of the Technological Pedagogical Content Knowledge scale varies significantly depending on gender in favor of females and this finding does not concur with the findings of the current study.

In the current study, it was found that Technological Knowledge sub-factor scores vary significantly depending on grade level and the mean score taken from this sub-factor by the third year students is significantly higher than that of the first year students. The reason for this difference might be that the third year students have already taken content courses such as Instructional Technologies and Materials Design and through such courses, they improved their technological knowledge. Thus, it can be argued that the courses taken by the pre-service teachers make positive contributions to their Technological Pedagogical Content Knowledge. It was found that the other sub-factors of the scale; Content Knowledge, Pedagogical Knowledge, Pedagogical Content Knowledge, Technological Content Knowledge, Technological Pedagogical Knowledge and Technological Pedagogical Content Knowledge do not vary significantly depending on grade level. This might lead us to think that the training taken by pre-service teachers during their undergraduate education cannot create any difference in terms of integration of technology into education, approaches to be adopted to deal with students and methods of instruction.

\section{Results and Suggestions}

In the current study investigating whether the pre-service classroom teachers' Technological Pedagogical Content Knowledge and knowledge about its sub-factors vary significantly depending on gender and grade level, following conclusions were reached:

- The pre-service classroom teachers' Technological Pedagogical Content Knowledge representing the whole scale does not vary significantly depending on gender and grade level.

- The pre-service classroom teachers' gender does not significantly affect their scores taken from the sub-factors of the TPCK scale; Technological Knowledge, Content Knowledge, Pedagogical Knowledge, Pedagogical Content Knowledge, Technological Content Knowledge, Technological Pedagogical Knowledge and Technological Pedagogical Content Knowledge.

- The Technological Knowledge sub-factor of TPCK scale varies significantly depending on grade level and this difference is in favor of the third year students.

- The other factors of the scale; Content Knowledge, Pedagogical Knowledge, Pedagogical Content Knowledge, Technological Content Knowledge, Technological Pedagogical Knowledge and Technological Pedagogical Content Knowledge do not vary significantly depending on grade level.

In light of these findings, following suggestions can be made;

- Pre-service teachers should be made aware of the importance of integrating technology into education.

- Pre-service teachers should be imparted with a viewpoint that pedagogical and content knowledge needs to be integrated and its importance should be emphasized.

- In future research, the effect of different variables on Technological Pedagogical Content Knowledge could be investigated.

- More in-depth analysis of the subject can be conducted by involving pre-service teachers from different faculties of different universities.

\section{References}

Çuhadar, C., Bülbül, T., \& Ilgaz, G. (2013). Investigation of the relationship between pre-service teachers' individualistic innovative characteristics and techno-pedagogical instructional competencies. Elementary Education Online, 12(3), 797-807.

Gömleksiz, M. N., \& Fidan, E. K. (2011). Turkish Studies-International Periodical for the Languages, Literature and History of Turkish or Turkic, 6(4), 593-620.

Harris, J. B., Mishra, P., \& Koehler, M. J. (2007). Teachers' technological pedagogical content knowledge: Curriculum-based technology integration reframed. Annual Meeting of the American Educational Research Association, Chicago, IL.

Heinich, R., Molenda, M., Russell, J. D., \& Smaldino, S. (2002). Instructional media and technologies for learning, 7th ed. Columbus: Merrill/Prentice Hall. 
Karasar, N. (2012). Scientific Research Method (23. Edition). Ankara: Nobel Yayın Dağıtım.

Kaya, Z., Özdemir, Y., Emre, G., \& Kaya, O. N. (2011). Determination of the pre-service technology teachers' technological pedagogical content knowledge self-efficacy levels. Paper presented at the International Computer \&

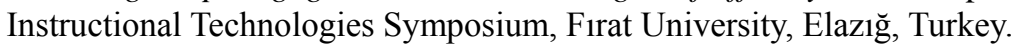

Koehler, M. J., \& Mishra, P. (2005a). Teachers learning technology by design. Journal of Computing in Teacher Education, 21(3), 94-102.

Koehler, M. J., \& Mishra, P. (2005b). What happens when teachers design educational technology? The development of technological pedagogical content knowledge. Journal of Educational Computing Research, 32(2), 131-152. https://doi.org/10.2190/0EW7-01WB-BKHL-QDYV

Koehler, M. J., \& Mishra, P. (2009). What is technological pedagogical content knowledge. Contemporary Issues in Technology and Teacher Education, 9(1), 60-70.

Komis, V., Ergazakia, M., \& Zogzaa, V. (2007). Comparing computer-supported dynamic modeling and 'paper \& pencil' concept mapping technique in students' collaborative activity. Computers \& Education, 49(4), 991-1017. https://doi.org/10.1016/j.compedu.2005.12.007

Kuşkaya-Mumcu, F., Haşlaman, T., \& Usluel, Y. K. (2008, May). The indicators of effective technology UInternational Educational Technology Conference, Anadolu University, Eskişehir, Turkey, 396-400.

Magnusson, S., Krajcik, J., \& Borko, H. (1999). Nature, sources, and development of pedagogical content knowledge for science teaching. InJ. GessNewsome \& N. G. Lederman (Eds.), Examining pedagogical content knowledge (pp.95-132). Dordrecht, The Netherlands: Kluwer.

Mandacı, Ş. S., Aydoğan, Y. A., Özpınar, İ., \& Köğce, D. (2013) Pre-service teachers' opinions about the components of a pre-service training program suitable for technological pedagogical content area knowledge model. Hacettepe University Education Faculty Journal, Special issue(1), 271-286.

McCannon, M., \& Crews, T. B. (2000). Assessing the technology needs of elementary school teachers. Journal of Technology and Teacher Education, 8(2), 111-121.

Mishra, P., \& Koehler, M. J. (2006). Technological pedagogical content knowledge: A frame work for teacher knowledge. The Teachers College Record, 108(6), 1017-1054. https://doi.org/10.1111/j.1467-9620.2006.00684.x

Niess, M. (2005). Preparing teachers to teach science and mathematics with technology: developing a technology pedagogical content knowledge. Teaching and Teacher Education: An International Journal of Research and Studies, 21(5), 509-523. https://doi.org/10.1016/j.tate.2005.03.006

Öztürk, E. (2013). Evaluation of pre-service classroom teachers' technological pedagogical content knowledge in terms of some variables, Uşak University Social Sciences Journal, 13, 223-238.

Öztürk, E., \& Horzum, M. B. (2011). Adaptation of technological pedagogical content knowledge scale into Turkish. Ahi Evran University Education Faculty Journal, 12(3), 255-278.

Sancar, T. H., Yavuz, K. G., \& Yanpar, Y. T. (2013). Investigation of the Mersin University pre-service pre-school teachers' self-efficacy perceptions of technological pedagogical content knowledge (TPCK). Kirşehir Education Faculty Journal, 14(1), 35-51.

Schmidt, D., Baran, E., Thompson, A., Mishra, P., Koehler, M. J., \& Shin, T. (2009). Technological Pedagogical Content Knowledge (TPACK): The development and validation of an assessment instrument for pre-service teachers. Paper presented at the 2009 Annual Meeting of the American Educational Research Association. April 13-17, San Diego, California. https://doi.org/10.1080/15391523.2009.10782544

Shulman, L. S. (1986). Those who understand; Knowledge growth in teaching. Educational Researcher, 15(2), 4-14. https://doi.org/10.3102/0013189X015002004

Timur, B., \& Taşar, M. F. (2011). Adaptation of technological pedagogical content knowledge self-efficacy scale (TPABÖGÖ) into Turkish. Gaziantep University Social Sciences Journal, 10(2), 839-856.

\section{Copyrights}

Copyright for this article is retained by the author(s), with first publication rights granted to the journal.

This is an open-access article distributed under the terms and conditions of the Creative Commons Attribution license which permits unrestricted use, distribution, and reproduction in any medium, provided the original work is properly cited. 